\title{
THE NORTH AMERICAN ANTS DESCRIBED BY ASA FITCH.
}

\author{
By William Morton Wheeler, \\ Bussey Institution, Harvard University.
}

Asa Fitch, in his well-known report on the insects infesting fruit and forest trees, first issued in $\mathbf{1 8 5 5}$ in the Transactions of the New York State Agricultural Society and in $\mathbf{1 8 5 6}$ as a separate volume, published descriptions and ethological notes on six species of common North American ants which he named the "cherry ant" (Myrmica cerasi Fitch), the "troublesome ant" (Myrmica molesta Say), the "silky ant" (Formica subsericea Say), the "wood-eating ant" (F. herculeana L.; $\boldsymbol{F}$. ligniperda Latr.), the "New York ant" $(\boldsymbol{F}$. noveboracensis Fitch) and the "walnut ant" ( $\boldsymbol{F}$. caryo Fitch). Hymenopterists have bestowed little attention on Fitch's work and have even misinterpreted some of his descriptions. A recent visit to the United States National Museum, where I found the types of his $\boldsymbol{F}$. noveboracensis and caryoe, has led me to study the descriptions of these and the other species with a view to determining the names by which they should now be known.

1. There is no difficulty in regard to Myrmica cerasi, which Emery was undoubtedly right in regarding as a distinct and easily recognizable color-variety of what had been previously described by Say (1836) as Myrmica lineolata, now known as Crematogaster lineolata var. cerasi Fitch.

2. Fitch described at length the habits of Myrmica molesta Say. Mayr, Forel, Dalla Torre and others believed Say's species to be merely the common house ant, Monomorium pharaonis L., because Say mentioned its occurrence in dwellings, but as Fitch describes it as nesting also "in our pastures and plowed fields and sometimes doing much injury in cornfields, gnawing the blades of corn when they are but a few inches high, for the purpose of drinking the sweet juice which flows from the wounds," it is evident that he refers to what Mayr later called Solenopsis debilis. The European myrmecologists were misled by their inability to believe that a small Solenopsis, closely allied to the European S. fugax Latr., could become a household pest. Many years ago I showed that this is really the case and supported Emery's contention that Say's 
species should be known as Solenopsis molesta (=debilis Mayr). Fitch's observations, which were unknown to me at that time, are additional confirmation of our view.

3. The silky ant, Formica subsericea Say, is, of course, the common form now regarded as merely a more pubescent variety of F. fusca L.

4. Fitch's description of $\boldsymbol{F}$. herculeana and ligniperda, which he evidently believed to be synonymous, shows that he referred to what we now call Camponotus herculeanus $\mathbf{L}$. subsp. pennsylvanicus DeGeer. He was thoroughly familiar with this insect and its habits.

5. Fitch's description of $F$. noveboracensis is very clear and shows that he had before him specimens of what Forel later called Camponotus ligniperdus var. pictus. Some years ago Pergande proved this from examination of Fitch's types. As ligniperda is merely a subspecies of herculeanus, the ant is now called $C$. herculeanus L. subsp. ligniperda Latr. var. noveboracensis Fitch. It should be noted that the last name is spelled "novceboracensis" by Fitch. It is, perhaps, permissible to amend so obvious an orthographic error.

6. On examining the types of Fitch's $F$. caryoe (several workers and females) in the National Museum I was surprised to find that they are identical with the form described by Emery in 1893 as Camponotus marginatus Latr. var. nearcticus. Emery subsequently discovered that Latreille's marginatus was a variety of C. maculatus Fabr. subsp. othiops Fabr. and that what Roger and later myrmecologists had been calling marginatus was really the form described by Nylander in 1856 as fallax. In my later papers I therefore referred nearcticus and a whole series of allied subspecies and varieties to Nylander's species. It is now evident that nearcticus becomes a synonym of caryo and that the closely related fallax of Europe, described a year later, becomes $C$. caryoe var. fallax Nyl. Hence the synonymy of the typical caryoe would stand as follows:

\section{Camponotus (Camponotus) caryo Fitch.}

Formica caryo Fitch, Trans. N. Y. State Agric. Soc. 14 (1854), 1855, pp. 855-859, $\Varangle,+\circ, \sigma^{7}$; First and Second Report on the Nox. Benef. and Other Ins. State N. Y., 1856, pp. 151-155; Third Report, 1859, p. 123. 
?Formica atra Buckley, Proc. Ent. Soc. Phila., 6, 1866, p. 160, \& . Camponotus marginatus Mayr (nec Latreille), Verh. Zoöl. bot. Ges. Wien. 36, 1886, p. 423 (in part).

C. marginatus var. nearcticus Emery, Zoöl. Jahrb. Abth. f. Syst. 7, 1893, p. 675, \& , $ᄋ$; Wheeler, Bull. Amer. Mus. Nat. Hist., 21, 1905, p. 402; Occas. Papers Boston Soc. Nat. Hist., 7, 1906, p. 24.

C. fallax Nyl. var. nearcticus Wheeler, Ann. Rep. N. J. State Mus. (1909), 1910, p. 663; Journ. N. Y. Ent. Soc., 18, 1910, p. 222; Ann. N. Y. Acad. Sci., 20, 1910, p. 342.

Both Cresson (Synops. Fam. Gen. Hymen., 1887, p. 255) and Dalla Torre (Catalog. Hymen., 7, 1893, p. 247) assumed that Fitch's $F$. caryo was merely a synonym of Camponotus pennsylvanicus, but, as we have seen, Fitch was well acquainted with this ant under the old name $\boldsymbol{F}$. herculeana and we could hardly suppose that so competent an entomologist would redescribe it under a new name. And although some of the distinctive characters are omitted in the description of caryo, it is, nevertheless, sufficiently explicit, even if the ethological notes and the types did not make the identification certain.

In conclusion the twenty described subspecies and varieties that must now be referred to the American caryo, as the specific type, instead of to the European fallax, together with their known distribution, may be listed as follows:

\section{North American Forms.}

C. caryo Fitch.-United States and British America.

var. minutus Emery.-United States and British America.

var. pardus Wheeler.-New York and New Jersey.

var. tanquaryi Wheeler.-Illinois.

var. decipiens Emery.-Indiana to Utah.

subsp. rasilis Wheeler.-Gulf States to Arizona.

var. pavidus Wheeler.-Gulf States.

subsp. subbarbatus Emery.-New Jersey to California.

var. paucipilis Emery.-Maryland.

subsp. discolor Buckley.-Texas to Illinois.

var. clarithorax Emery.-Pennsylvania to California.

var. cnemidatus Emery.-Maryland. 
Eurasian Forms.

C. caryo var. fallax Nyl.-Southern Europe.

var. ruzskyi Emery.-Russia.

var. lameerei Emery.-Tashkund.

var. kamensis Ruzsky.-Kasan.

var. himalayanus Forel.-Himalayas.

var. quadrinotatus Forel.-Japan.

var. nawai Ito. Japan.

subsp. vitiosus F. Smith.-Japan.

subsp. brunni Forel.-Japan.

\title{
A NEW MALAYAN ANT OF THE GENUS PRODISCOTHYREA.
}

\author{
By William Morton Wheeler, \\ Bussey Institution, Harvard University.
}

Prodiscothyrea bryanti sp. nov.

Worker: Length, $2 \mathrm{~mm}$. Very similar to the genotype $P$. velutina, which I recently described from Queensland, Australia (Trans. Royal Soc. South Australia, 40, 1916, pp. 33-37, Pl. 4), but differing in the following characters: The head is proportionally smaller and much less convex above, especially behind the frontal carinæ, the eyes are much smaller and the cheeks have a more prominent blunt tooth in front of the eyes. The antennal scapes are less abruptly narrowed at the base and the funicular joints, with the exception of the last are even more transverse, so that the whole funiculus is shorter, being scarcely longer than the scape. Thorax shorter, not $1 \frac{1}{2}$ times as long as broad, less convex in front, with less angular humeri and with more distinct epinotal teeth and more nearly vertical epinotal declivity. Petiole much smaller and broader, nearly four times as broad as long and with a more pronounced, compressed, translucent tooth on its ventral surface. Postpetiole also shorter, less decidedly narrowed in front and less depressed above in front than in velutina. Sculpture, pubescence and color very similar to those of velutina but the dark median dorsal line on the postpetiole and first gastric segment is lacking.

Described from a single specimen taken on Penang Island in the Straits Settlements by Mr. G. E. Bryant and sent me by Mr. 

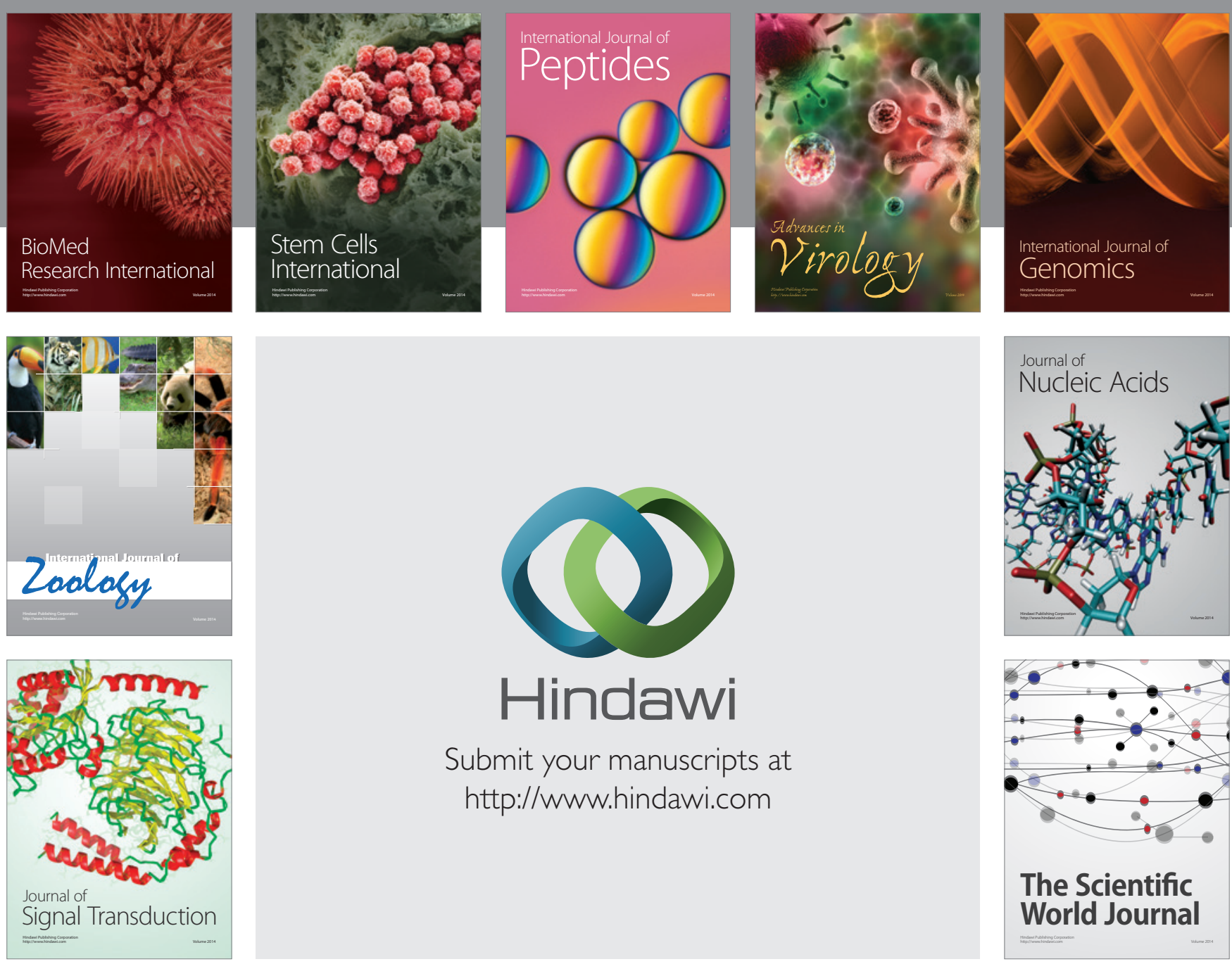

Submit your manuscripts at

http://www.hindawi.com
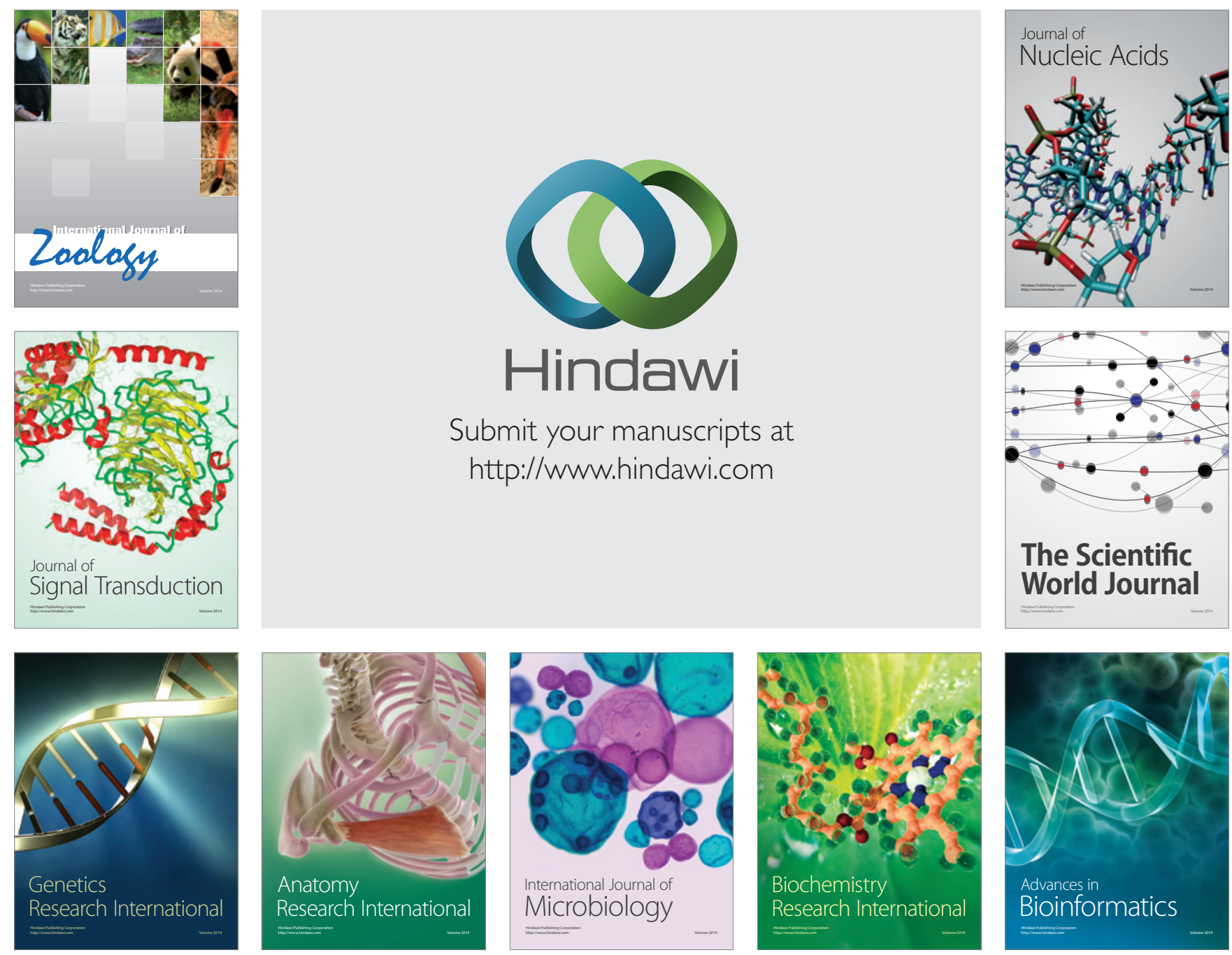

The Scientific World Journal
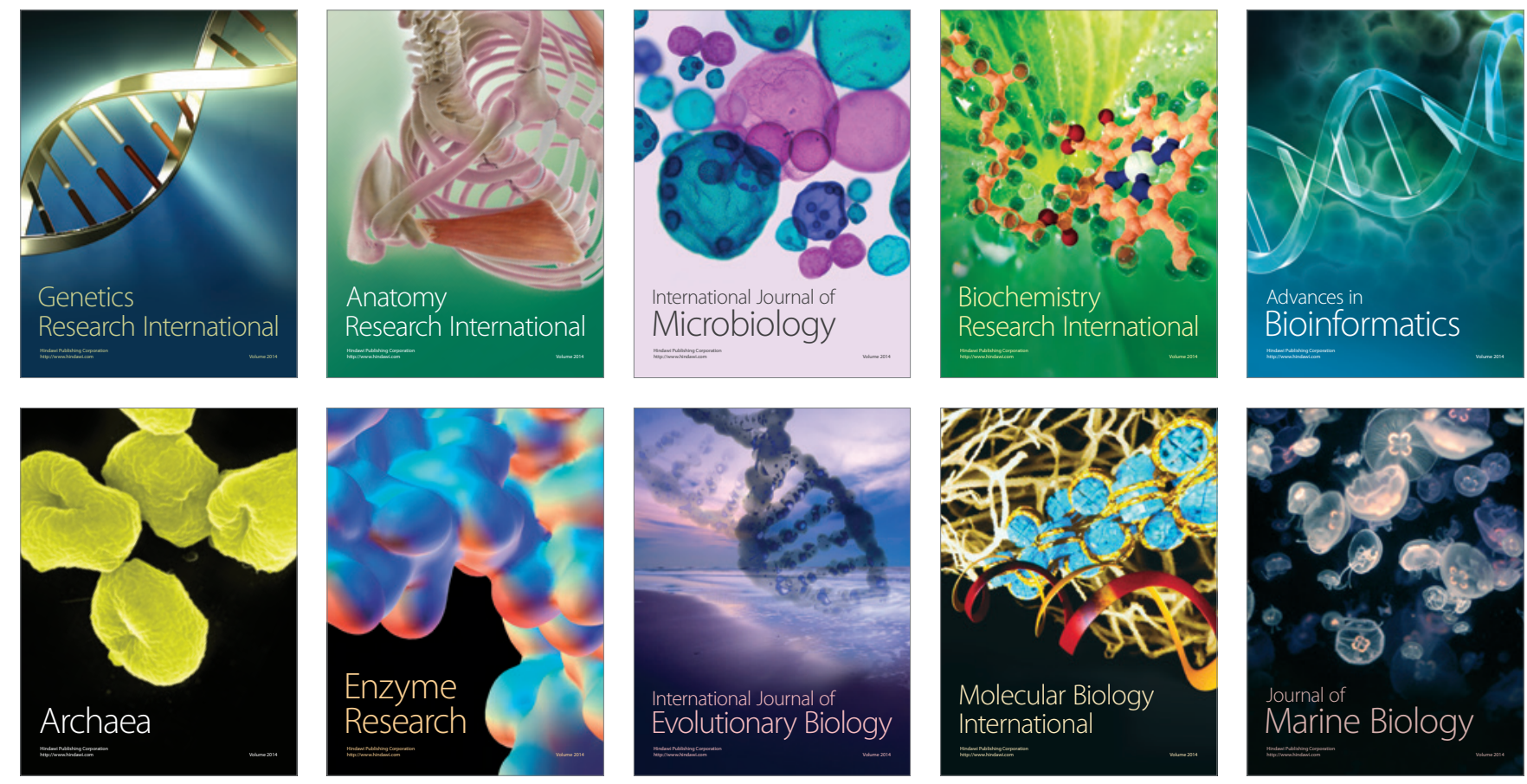